\title{
Case Report \\ Measurement and Mitigation of Radon Concentration in a Traditional Dwelling in Galicia, Spain
}

\author{
Ricardo Pol ${ }^{1,2,3, *}$, Raúl Rodríguez ${ }^{1,2,3}$, Luis Santiago Quindós ${ }^{1}$ and Ismael Fuente ${ }^{1}$ (D) \\ 1 Natural Radioactivity Laboratory (LaRUC), University of Cantabria, 39011 Santander, Spain; \\ raul.rodriguezal@alumnos.unican.es (R.R.); luis.quindos@unican.es (L.S.Q.); ismael.fuente@unican.es (I.F.) \\ 2 Escuela Técnica Superior de Ingenieros de Caminos, Canales y Puertos, University of Cantabria, \\ 39005 Santander, Spain \\ 3 Research \& Development Department, Siglo 21 Consultores SL, 15172 La Coruna, Spain \\ * Correspondence: ricardo.pol@alumnos.unican.es
}

Citation: Pol, R.; Rodríguez, R.; Quindós, L.S.; Fuente, I. Measurement and Mitigation of Radon Concentration in a Traditional Dwelling in Galicia, Spain. Atmosphere 2022, 13, 14. https:// doi.org/10.3390/atmos13010014

Academic Editor: Cucos (Dinu) Alexandra

Received: 26 November 2021 Accepted: 15 December 2021 Published: 23 December 2021

Publisher's Note: MDPI stays neutral with regard to jurisdictional claims in published maps and institutional affiliations.

Copyright: (C) 2021 by the authors. Licensee MDPI, Basel, Switzerland. This article is an open access article distributed under the terms and conditions of the Creative Commons Attribution (CC BY) license (https:// creativecommons.org/licenses/by/ $4.0 /)$.

\begin{abstract}
Radon is a naturally occurring radioactive gas which tends to build up within structures It is therefore necessary to include techniques to mitigate radon concentration when undertaking refurbishment. The goal of this study is to assess the effectiveness of a mitigation technique based on pressurizing the interior of a building, by testing a prototype of the mitigating device, developed by Siglo 21 Consultores and the LaRUC of the University of Cantabria, under real conditions, to determine its effectiveness during refurbishment. The methodology involved installing the proposed solution in a traditional country dwelling in an area characterized by high radon concentration, on the coast of Galicia, Spain. In order to measure the effectiveness of the solution, continuous measurement sensors, set in an ionization chamber, and properly calibrated by the LaRUC laboratory, were installed. The results obtained show that pressurizing the living quarters brings about an effective reduction in the radon concentration, with a relatively simple building solution. This solution, which is compatible with the principle of minimum intervention, is seen to be especially appropriate when work is undertaken in structures recognized as heritage.
\end{abstract}

Keywords: radon; heritage; mitigation; refurbishment; air quality

\section{Introduction}

Build-up of radon gas inside structures is one of the main causes of death from lung cancer among nonsmokers. Concentration values of $200 \mathrm{~Bq} / \mathrm{m}^{3}$ may be a risk factor for the development of the disease [1-4]. It is estimated that from $15 \%$ and $25 \%$ of cases of the disease stem from this pathology of buildings. This value is below the limit of $300 \mathrm{~Bq} / \mathrm{m}^{3}$ set by Directive 2013/59/EURATOM, and is twice the $100 \mathrm{~Bq} / \mathrm{m}^{3}$ set as the reference level to minimize health risks from indoor exposure to radon [5]

Recommendations published by national and international public bodies on radon mitigation offer a catalogue of solutions based on different strategies [6,7]: ventilating premises, positively pressurizing the premises and the ground, depressurizing the ground under the building, and setting up barriers the gas cannot breach.

Carrying out these mitigation techniques in existing buildings is met with many difficulties, typical of work undertaken on an already built structure. These building difficulties come from the interaction with other existing elements, such as old facilities and services installed in the structure, and also from problems of protected features, due to heritage status, which must be addressed jointly with the questions of esthetics, hygiene and comfort of the living area. The strategy based on positively pressurizing the premises thus has significant advantages when undertaking work on existing buildings, especially those of architectural and cultural value. It is true, however, that it does have disadvantages, such as those arising from the degree of airtightness of the surrounding structure, as with highly permeable surroundings it can be difficult to achieve the required pressure difference 
at all times. Another matter to be considered is the effect of the actions of users who, upon entering or leaving the building, or opening or closing the windows, cause variations in the internal pressure [8].

The aim of this study is to assess the effectiveness of the positive pressure strategy in a traditional single-family dwelling in an area given to high concentrations of radon, to quantify to what extent the problems mentioned in the scientific literature compromise the effectiveness of the solution, and to use a real case study to check the effectiveness of this technique in situations in which the concentration is above $500 \mathrm{~Bq} / \mathrm{m}^{3}$, since, according to the criteria of Public Health England [7] the strategy would not be recommended in this situation.

The possibility of testing a prototype of the mitigating device based on this pressurization strategy in a real case allows the effectiveness of the technique to be evaluated, bearing in mind the large number of variables to be taken into account in any refurbishment work on a protected heritage structure (cost of the work, esthetic concerns, energy efficiency, heat and noise levels, and heritage concerns, and always with a special interest in efficiency, economy and minimum intervention).

Due to its characteristics, this solution is ideal for seeking a balance between effectiveness and cost, minimizing the impact of the activity.

\section{Materials and Methods}

\subsection{Location of the Building}

The building used in the study is a traditional single-family dwelling in the province of A Coruña, within the authority of the Town Council of Ferrol, Parish of Doniños, in a Lake area, $\left(43^{\circ} 30^{\prime} 38.5^{\prime \prime} \mathrm{N}, 8^{\circ} 18^{\prime} 11.1^{\prime \prime} \mathrm{W}\right)$, at a height of $57 \mathrm{~m}$ above sea level (see Figure 1), corresponding to climate area C1 (Royal Decree 732/2019, which amends the Technical Building Code (TBC), set out in Royal Decree 314/2006), with an accumulated monthly rainfall of $150 \mathrm{~mm}$ in the winter months, 125 days of rainfall annually, [9], relative humidity of $75 \%$, and ranked with a Köppen index of Cfb.
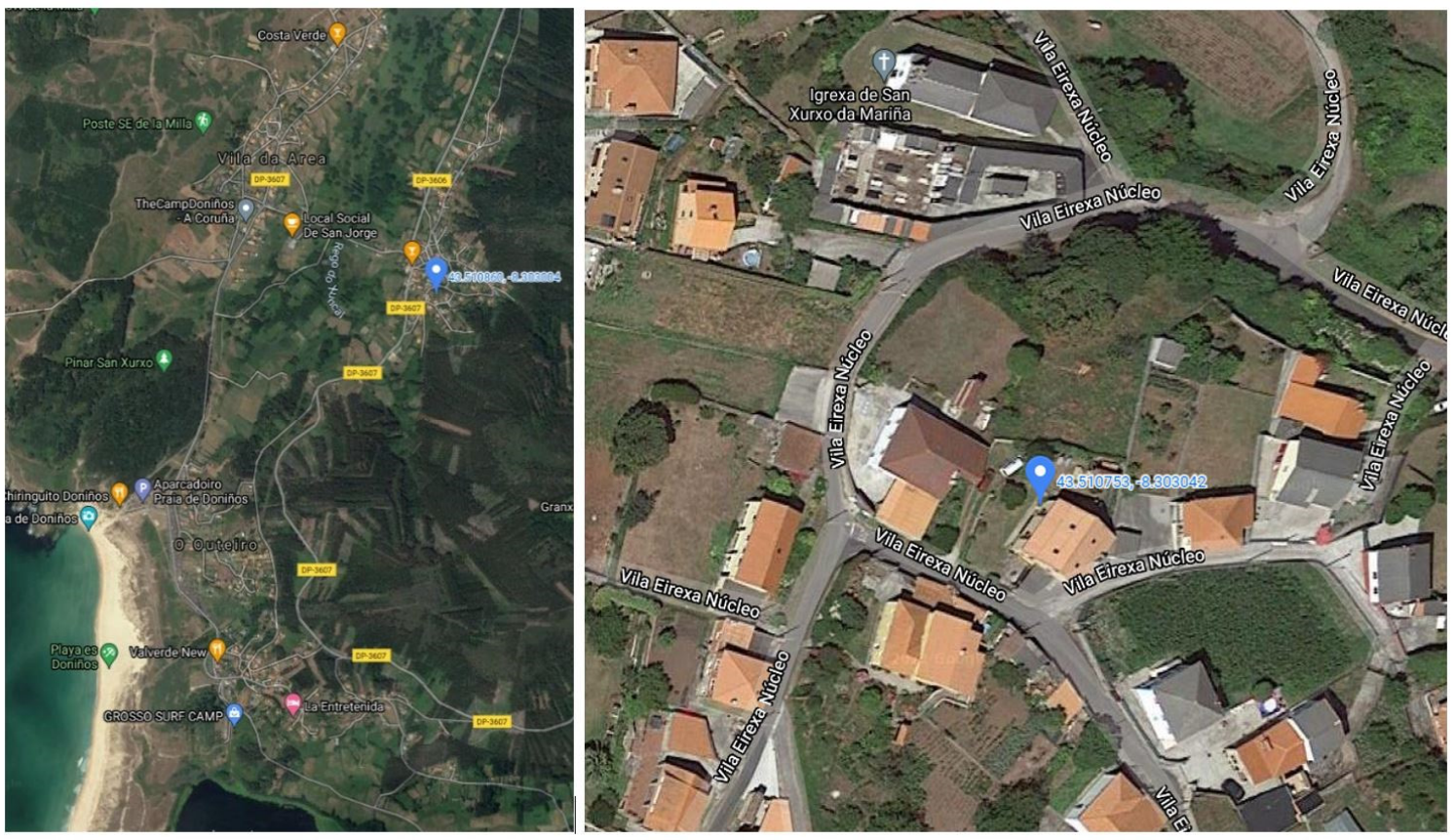

Figure 1. Location of the building. Source: Google Maps.

With respect to its topographic conditions, the site is located on a westerly facing slope and is exposed to prevailing winds from the south-west. The ground is mostly composed of the typical granite of the Galician Massif, characterized by its age, with a high level of 
weathering and poor consistency. Native presence of trees in the area comprises mainly Pinus pinaster, which has a very strong root system with a penetrating main root and well-developed secondary roots, which increase weathering of the rocky substrate, leading to cracking which allows radon to enter buildings.

The plot is in a geographical area classified as having a high radon potential, in the 90th percentile (P90) of radon distribution levels among buildings in the area [10] greater than $400 \mathrm{~Bq} / \mathrm{m}^{3}$.

\subsection{Type and Morphology}

The building used for the tests is a traditional rural dwelling of the type characteristic of the countryside of A Coruña [11], with $60 \mathrm{~cm}$ thick stone walls of local granite, which produce very high thermal inertia, wooden beams of local oak and pine boards, and a gabled tile roof on openwork brick supports, which are highly permeable to the air.

The building is compact, rectangular in shape, with openings for light and ventilation of a size appropriate to the style. These openings in the external walls are closed with modern lacquered aluminum windows which give a high level of airtightness. The floor plan, as is usual in this type of structure, was originally of a single story, probably with a slate floor. Currently, after the refurbishment, the floors were finished with stone tiles laid on a thin layer of mortar.

\subsection{Identification of Sources}

As a result of the measurements taken in advance, it was found that the high concentrations of radon come mainly from the soil below the building, which, because of the way it was built (one floor, directly on the soil), favors the entry of gas.

Following the consensus among a number of authors [5,12] the building materials of the dwelling, mainly local wood and granite, are not considered a possible primary source, although granite cannot be ruled out as a secondary source, with a contribution no greater than $20-30 \%$ [13].

\subsection{Measurement Strategies}

The owners of the premises had already taken measurements, before the actions here described, giving values between 600 and $900 \mathrm{~Bq} / \mathrm{m}^{3}$.

In order to understand the initial situation, a continuous measurement was taken with a SCOUT model SARAD device, calibrated by the University of Cantabria Radon Laboratory (LaRUC), over a period of two months, which gave an average concentration of $686 \mathrm{~Bq} / \mathrm{m}^{3}$ over the period of measurement. In total, $70 \%$ of these measurements were taken outside the heating season, and so an average annual value of $960 \mathrm{~Bq} / \mathrm{m}^{3}$ can be obtained, applying the correction factor set out in DB HS6 of the Technical Building Code [14].

In order to gain a detailed understanding of the fluctuations in radon concentrations, and the effectiveness of the mitigation measures taken, a continuously measuring radon sensor was installed in the dwelling. This was a RICO Wireless model of the Interface ${ }^{\circledR}$ brand (A Coruña, Spain), using ionization chamber technology, with a calibration certificate from LaRUC (see Figure 2). This device allows the data gathered to be viewed in real time over the Internet.

\subsection{Mitigation Strategy}

Bearing in mind that the concentration originates from the identified sources, and given the characteristics of the climate and geology of the site, the concentration values reached inside the dwelling are assumed to result from an accumulation of gas via convection and advection. 


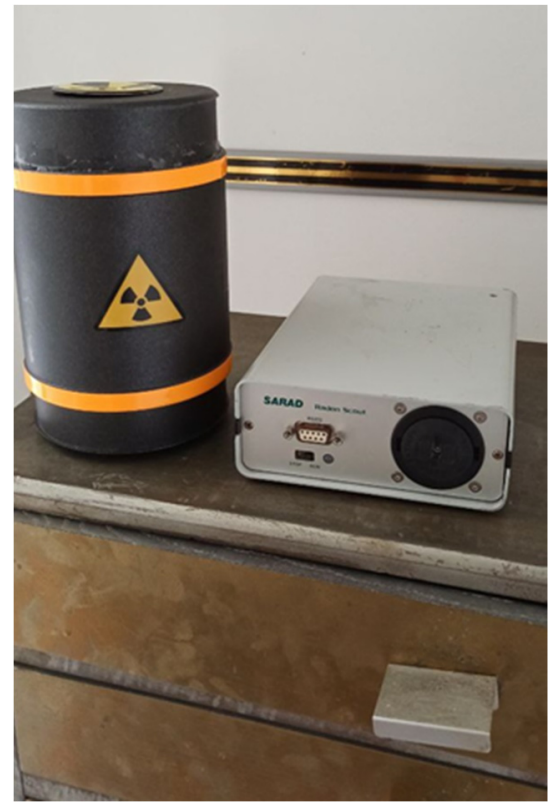

Figure 2. Measuring devices. Source: photo by author.

Given that "... it has been confirmed that an increase in the pressure leads to a decrease in the concentrations of radon, and that an increase in humidity increases these concentrations" [15], the mitigation strategy based on pressurizing the inside of the dwelling does both of these things, increasing the pressure and reducing the humidity due to the excess ventilation.

While it is true that, for the concentration values in question, the standards set by relevant bodies (TBC, Consellería de Ordenación del Territorio and Public Health England) agree that the interior pressurization method is not to be recommended for levels above $500 \mathrm{~Bq} / \mathrm{m}^{3}$ [7], in this case a mitigating device is being tested based on this technique, to determine whether the newest generation of devices can be, in agreement with the manufacturers specifications, effective against high concentrations (in the range 100 to $4000 \mathrm{~Bq} / \mathrm{m}^{3}$ ), since, bearing in mind the advantages this offers, it would seem to be the ideal solution in the situation considered here.

The prototype tested is an active mitigator of the brand Interface ${ }^{\circledR}$ (A Coruña, Spain), developed by Siglo 21 Consultores together with the LaRUC, and part of a preseries of two units, about which no further information can be given at the time of writing this paper as it is subject to a patent recognition process. It can be stated, however, that the working of the mitigator is based on pumping into the interior of the building, clean, dry air from the outside, with sufficient flow to maintain a positive pressure differential between inside and outside, in order to make it more difficult for radon from the ground beneath the building to penetrate inside.

The device reduces the concentration of radon gas through the use of a fan driven by electrical energy that injects a certain air flow from outside.

It also incorporates an activated carbon filter that prevents the passage of coarse particles (diameter less than or equal to 10 microns- $\mu \mathrm{m}$ ) in order to guarantee that this air is clean of contaminants.

This air flow, which passes through the filter, is led by the fan towards an exchanger that heats or cools it depending on the chosen option. Two different exchangers are designed based on the pre-existing air conditioning technology in the building. In this case, the building is air-conditioned by means of a system based on biomass combustion, and the mitigator incorporates an electrical resistance and a solid-air exchanger. The combination of filter plus exchanger guarantees the quality of the interior air and solves the thermal aspect of the comfort. A suppressor is incorporated into this flow sequence that guarantees acoustic comfort by lowering the noise level of the unit. 
The device, in accordance with the manufacturer's instructions, was placed on the outside of the building in an IP-65 rated box, which is linked to the dwelling through a ventilation duct in the outside wall.

\subsection{Installation of the Device}

The device was placed on the ground floor, as it is in contact with the source. To minimize the impact of the activity, the device was placed next to the north face of the building (see Figures 3 and 4), with access to the kitchen through the wall below the windowsill. At this point the wall was thinner due to the narrowing of the opening, which made installation easier.

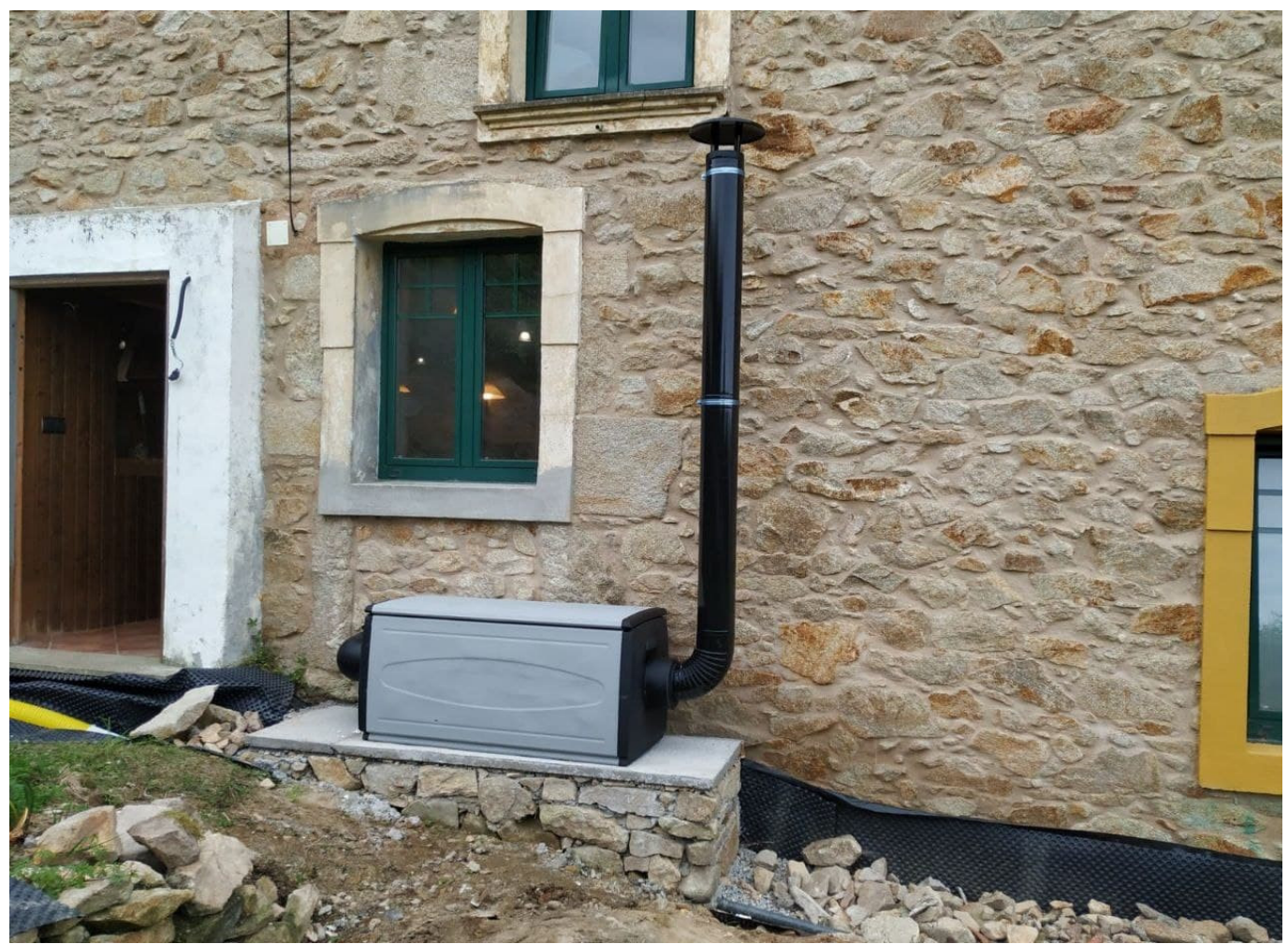

Figure 3. Mitigating device. Source: photo by author.

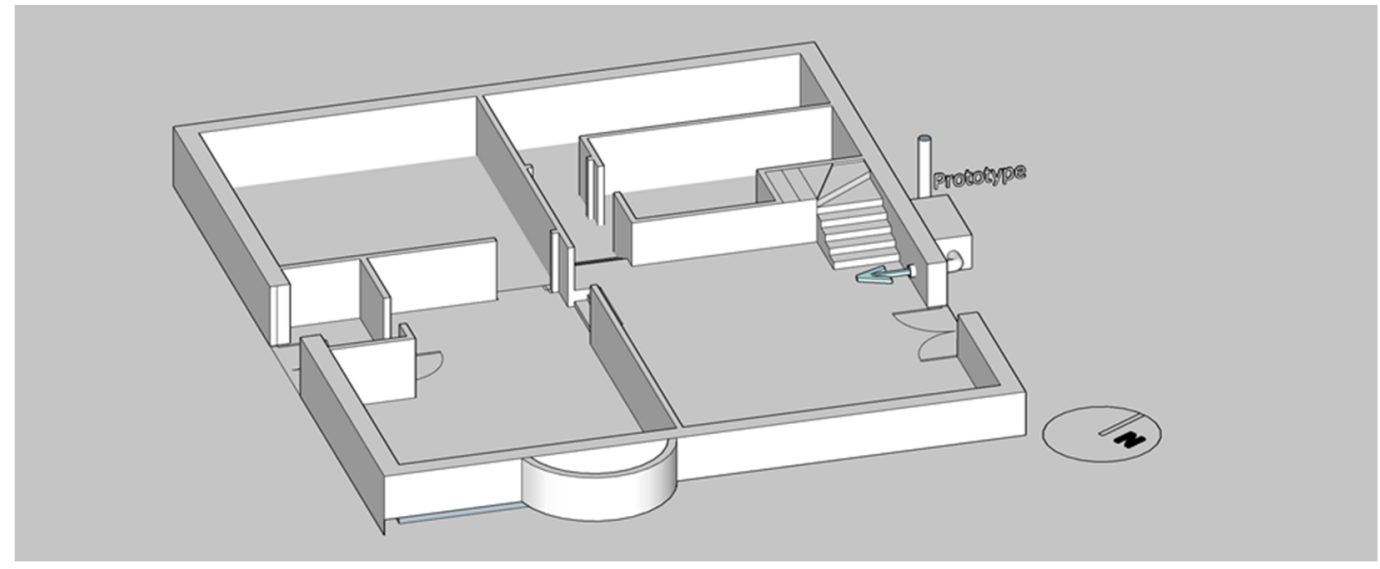

Figure 4. Plan of the installation. Source: created by author.

An Internet-linked RICO Wireless sensor, whose operation could be monitored in real time, was installed in order to assess the effectiveness of the solution proposed. 


\subsection{Prior Operations to Prepare the Building}

Before placing the device, a highly detailed study was undertaken of the convective air currents inside the building, and the most appropriate site was chosen as a result.

Given the high permeability of the surrounding structure, which is especially apparent in the Arabic tile roof, on wooden boards, resting on supports and beams of the same material, it was decided to position a kind of sluicegate on the stairway leading to the upper floor, to minimize pressure loss from the ground floor.

\section{Results and Discussion}

\section{Results of the Corrective Measure}

Once the installation work was finished, and before putting the device in operation, a prior measurement of the concentration was taken continuously over $48 \mathrm{~h}$, with the purpose of determining the natural value of the concentration, which was found to be $(686 \pm 47)(\mathrm{k}=2) \mathrm{Bq} / \mathrm{m}^{3}$ on average. The device was switched on at 12:00 on the 28 May, when the concentration inside the dwelling was $831 \mathrm{~Bq} / \mathrm{m}^{3}$ (see Figure 5). After $60 \mathrm{~min}$, the concentration had dropped $28.40 \%$ to $595 \mathrm{~Bq} / \mathrm{m}^{3}$. Over the next few hours, the concentration continued to drop at the same rate, down to $90 \mathrm{~Bq} / \mathrm{m}^{3}$ at $16.00 \mathrm{~h}$, and the concentration remained stable below $100 \mathrm{~Bq} / \mathrm{m}^{3}$.

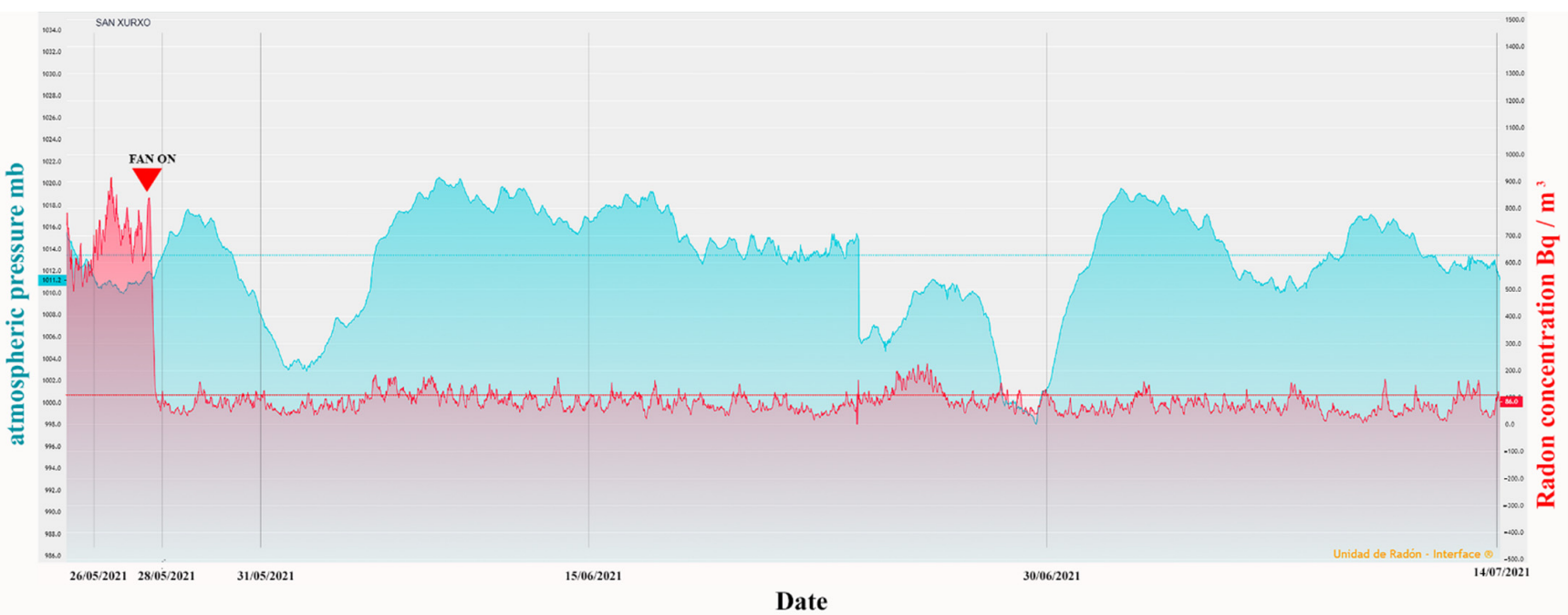

Figure 5. Graph of radon concentration from 26 May 2021 to 14 July 2021.

Monitoring of the radon levels inside the dwelling continued over the next two months, using two continuous measurement devices placed within it: the first, a RICO model Interface ${ }^{\circledR}$ sensor calibrated by LaRUC [16], which gave an average exposure of (70 \pm 7$)$ $(\mathrm{k}=2) \mathrm{Bq} / \mathrm{m}^{3}$, and as a contrast a second device, a SCOUT model SARAD calibrated by LaRUC [16], was used, which returned an average exposure of $(76 \pm 17)(\mathrm{k}=1) \mathrm{Bq} / \mathrm{m}^{3}$ over the same period.

\section{Conclusions}

The results obtained are below the reference level set by the WHO for protection against exposure to natural radiation, and show empirically the effectiveness of mitigation based on pressurizing the inside of the dwelling in situations where concentration values are above $500 \mathrm{~Bq} / \mathrm{m}^{3}$, in contradiction to the guidelines of the UK Government and the TBC.

The device tested responded immediately by reducing the concentration and keeping it stable in the normal conditions of use of the dwelling, and also helped to alleviate the problems caused by the high humidity of the area, and improved the quality of factors relating to health and humidity inside the house. 
It is worth noting the ease with which the installation was carried out, as it was completed in two hours by a single workman. The limited impact on the existing structure is also worth noting: only one opening in a wall was necessary, and the device was connected to the grid simply by plugging it into a Type F Schuko socket (Standard CEE 7), a procedure which is highly recommended when working in built heritage.

Another point in favor of this solution is the speed with which it can be undertaken, and its low cost compared to alternative solutions, such as placing radon barriers or creating suction wells.

Negative aspects include the fact that the device produces some noise, as $46 \mathrm{~dB}$ were registered at $1 \mathrm{~m}$ from the exit point, which could be a problem for the comfort of those in the dwelling. It is therefore recommended that, insofar as possible, the entry points should be sited away from the areas most frequented by the inhabitants.

This study is part of an investigation whose objective is analyzing the effectiveness of the indoor pressurization technique in rehabilitation actions on the built heritage [17].

\section{Patents}

The prototype tested in this experiment is an invention of the authors, and at the time of writing this paper it is subject to a patent recognition process.

Author Contributions: Conceptualization, R.P., R.R. and L.S.Q.; methodology, R.P. and R.R.; software, R.R.; validation, R.P. and R.R.; formal analysis, R.P. and R.R.; investigation, R.P.; resources, R.P., R.R., L.S.Q. and I.F.; data curation, R.P. and R.R.; writing-original draft preparation, R.P. and R.R.; writing-review and editing, L.S.Q. and I.F.; visualization, R.P. and R.R.; supervision, L.S.Q.; project administration, L.S.Q. and I.F.; funding acquisition, R.P. All authors have read and agreed to the published version of the manuscript.

Funding: The Article Processing Charges were funded by Industrial doctorate program of the University of Cantabria.

Institutional Review Board Statement: Not applicable.

Informed Consent Statement: Not applicable.

Conflicts of Interest: The authors declare no conflict of interest. The funders had no role in the design of the study; in the collection, analyses, or interpretation of data; in the writing of the manuscript, or in the decision to publish the results.

\section{References}

1. Barros-Dios, J.; Barreiro, M.; Ruano-Ravina, A.; Figueiras, A. Exposure to residential radon and lung cancer in Spain: A population-based case-control study. Am. J. Epidemiol. 2002, 156, 548-555. [CrossRef] [PubMed]

2. Samet, J.M.; Eradze, G.R. Radon and Lung Cancer Risk: Taking Stock at the Millenium. Environ. Health Perspect. 2000, 108, 635-641. [CrossRef] [PubMed]

3. Hill, D.; Auvinen, A.; Barros-Dios, J.; Baysson, H.; Bochicchio, F.; Deo, H.; Falk, R.; Forastiere, F.; Hakama, M.; Heid, I.; et al. Radon in homes and risk of lung cancer: Collaborative analysis of individual data from 13 European case-control studies. BMJ 2005, 330, 223. [CrossRef]

4. Branion-Calles, M.; Nelson, T.; Henderson, S. A geospatial approach to the prediction of indoor radon vulnerability in British Columbia, Canada. J. Exp. Sci. Environ. Epidemiol. 2015, 26, 554-565. [CrossRef] [PubMed]

5. Zeeb, H.; Shannoun, F.; Organización Mundial de la Salud. Manual de la OMS sobre el Radón en Interiores: Una Perspectiva de Salud Pública. Organización Mundial de la Salud. 2015. Available online: https://apps.who.int/iris/handle/10665/161913 (accessed on 2 August 2021).

6. Frutos, B.; Olaya, M.; Esteban, J.L. Sistemas de extracción como técnicas constructivas para evitar la entrada de gas radón en las viviendas. Inf. Constr. 2011, 63, 23-36. [CrossRef]

7. Public Health England. UKradon-How to Reduce Radon Levels. 2021. Available online: https://www.ukradon.org/ information/reducelevels (accessed on 2 August 2021).

8. International Atomic Energy Agency. Protection against Exposure Due to Radon Indoors and Gamma Radiation from Construction Materials-Methods of Prevention and Mitigation. International Atomic Energy Agency. 2021. Available online: https: / www.iaea.org/publications /14817/ protection-against-exposure-due-to-radon-indoors-and-gamma-radiationfrom-construction-materials-methods-of-prevention-and-mitigation (accessed on 2 August 2021). 
9. Chazarra Bernabé, A.; Flórez García, E.; Peraza Sánchez, B.; Tohá Rebull, T.; Lorenzo Mariño, B.; Criado Pinto, E.; Moreno García, J.V.; Romero Fresneda, R.; Botey Fullat, R. Mapas Climáticos de España (1981-2010) y ETo (1996-2016)—Agencia Estatal de Meteorología-AEMET. Gobierno de España. Área de Climatología y Aplicaciones Operativas. 2018. Available online: http://www.aemet.es/es/conocermas/recursos_en_linea/publicaciones_y_estudios/publicaciones/detalles/ MapasclimaticosdeEspana19812010 (accessed on 2 August 2021).

10. Consejo de Seguridad Nuclear. Mapa del Potencial de Radón en España-CSN. 2017. Available online: https: / /www.csn.es / mapa-del-potencial-de-radon-en-espana (accessed on 2 August 2021).

11. de Llano, P. Arquitectura Popular en Galicia; COAG: Santiago de Compostela, Spain, 1981.

12. Frutos Vázquez, B.; Muñoz Lorenzo, E. Radon en la Edificacion. Tecnicas de mitigacion. In Proceedings of the Jornada de Contaminación por Gas Radón. Avances y Desarrollos en el Ámbito de la Protección, Madrid, Spain, 14 December 2016.

13. Quindós Poncela, L.S. Radón: Un Gas Radiactivo de Origen Natural en Su Casa; Consejo de Seguridad Nuclear: Madrid, Spain, 1995.

14. Agencia Estatal Boletín Oficial del Estado (AEBOE). Real Decreto 732/2019, de 20 de Diciembre, por el Que se Modifica el Código Técnico de la Edificación, Aprobado por el Real Decreto 314/2006, de 17 de Marzo, Pub. L. No. Real Decreto 732/2019, BOE-A-2019-18528 140488. 2019. Available online: https://www.boe.es/eli/es/rd/2019/12/20/732 (accessed on 2 August 2021).

15. Ramirez Fernandez, M.P.; Moron Fernandez, C.; García García, A.; Correa, E. Estudio de las Concentraciones y Mecanismos de Desplazamiento de Radón y Descendientes en Recintos Cerrados. Actas del Congreso de Innovación Tecnológica en la Edificación CITE-2011. Madrid, España, 179-184. 2011. Available online: http:/ / oa.upm.es/13446/ (accessed on 2 August 2021).

16. Rabago, D.; Fuente, I.; Celaya, S.; Fernandez, A.; Fernandez, E.; Quindos, J.; Pol, R.; Cinelli, G.; Quindos, L.; Sainz, C. Intercomparison of Indoor Radon Measurements Under Field Conditions In the Framework of MetroRADON European Project. Int. J. Environ. Res. Public Health 2020, 17, 1780. [CrossRef] [PubMed]

17. Pol, R.; Rodríguez, R.; Quindos, L.; Fuente, I. Mitigation Techniques for Interior Radon in Refurbishment Work in High Radiation Areas of Galicia: An Experimental Model to Test Building Solutions. Civ. Environ. Eng. 2021, 17, 485-499. [CrossRef] 